\title{
Esfera Pública e Política Radical: Apontamentos a Partir de Habermas ${ }^{1}$
}

\author{
Leno Francisco Danner ${ }^{2}$
}

\begin{abstract}
RESUMO: O artigo discute a noçâo de esfera pública tematizada nos trabalhos habermasianos, defendendo que a íntima associação entre esfera pública e democracia permite pensar um modelo de política radical, no qual a aproximação entre Estado burocrático e partidos políticos profissionais com os movimentos sociais e as iniciativas cidadâs poderia superar a redução da práxis política a política partidária, concedendo a devida importância aos impulsos normativos e aos interesses generalizáveis advindos da sociedade civil rumo ao político, recuperando também uma concepção de esfera pública não desvirtuada por formas de comunicação ideológicas ou distorcidas, inclusiva e crítica do poder. Para isso, entretanto, a práxis política necessitaria, correlatamente àquela aproximaçáo, dar um passo além da própria esfera pública concentrada na mídia corporativa, adentrando nas esferas públicas informais desenvolvidas pelos movimentos sociais e pelas iniciativas cidadãs. Com efeito, as acusaçôes, por Habermas, de subversão da esfera pública das democracias de massa contemporâneas somente poderiam ser superadas a partir de uma maior ênfase em tais esferas públicas informais, que também poderiam dinamizar uma organização administrativo-partidária atualmente marcada pelo distanciamento e pela sobreposiçấo em relação à sociedade civil - situação possibilitada, em grande medida, pela mídia corporativa e pela burocracia e elitismo partidários.
\end{abstract}

PALAVRAS-CHAVE: Esfera Pública. Democracia. Subversão. Esfera Pública Informal. Política Radical.

\section{Do SOlapamento da eSFERa pública À POSSIBILIDADE DE UMA DEMOCRACIA RADICAL}

Analisando-se cronológica e sistematicamente os trabalhos de Habermas, é sintomática a percepção de que a noção de esfera pública desempenhe, conforme penso, um papel fundamental em todos os seus escritos políticos, seja enquanto categoria sociológica, seja - que é o que me interessa aqui - enquanto categoria filosófico-normativa. Ela apareceu pela primeira vez em Mudança Estrutural da Esfera Pública, em ambos os sentidos, de modo a, por um lado, servir de paradigma sociológico orientador de avaliaçôes empíricas da dinâmica da Realpolitik das sociedades democráticas do século XX (em termos de capitalismo

\footnotetext{
${ }^{1}$ http://dx.doi.org/10.1590/S0101-31732015000300009

${ }^{2}$ Doutor em Filosofia (PUC-RS). Professor de Filosofia e de Sociologia na Fundação Universidade Federal de Rondônia (UNIR). E-mail: leno_danner@yahoo.com.br
} 
tardio) e, por outro, permitindo diagnósticos em um sentido normativo sobre a autoconstituição de tais sociedades enquanto democracias. O modelo de esfera pública burguesa, por conseguinte, serviu para a idealização de uma concepção de publicidade política que, enquanto instrumento normativo, favorecia a comparação com processos correntes de justificação institucional em sua relação com a participação (ou não) dos cidadãos e dos grupos sociais nas tomadas de decisão possibilitadas (ou não) pelos sistemas sociais contemporâneos constituídos, conforme dito acima, como democracias. Note-se, em relação a isso, que um dos significados mais específicos do conceito de democracia remetese à publicidade das (e ao grau de inclusão possibilitado pelas) tomadas de decisão institucionais que a rigor deveriam não apenas ser levadas a conhecimento do público de cidadãos, mas também justificadas permanentemente aos mesmos e contando com sua participação efetiva.

Nesse diapasão, duas constataçōes Mudança Estrutural da Esfera Pública consagrou nas posições de Habermas, que tiveram e têm eco em todos os seus trabalhos daí advenientes: (a) as revoluçóes burguesas modernas instauraram uma ideia de justificação pública que transladou o núcleo do poder, anteriormente congregado na instituição Estado ou monarca, enquanto fim em si mesmo, para o centro da arena política constituída pela esfera pública, dinamizada por uma sociedade civil altamente contraposta ao poder do Estado ou do rei e exigente de uma permanente justificaçáo das açóes governamentais - a partir da segunda metade do século XIX, os movimentos proletáriosocialistas assumiram esse ideal de uma esfera pública política enquanto arena de uma política radical, servindo de contraponto e de complemento ao poder administrativo-partidário, normativamente enraizada, colocando-a como o cerne de suas lutas por emancipaçáo, tâo importante quanto a própria esfera administrativo-parlamentar (cf. HABERMAS, 1984, $₫ 08$, p. 84-85; HABERMAS, 1987, p. 83; GOODE, 2005, p. 05-12); e (b) as democracias de massa contemporâneas estariam sendo marcadas por um processo de solapamento desse potencial político da sociedade civil, na medida em que a esfera pública e seu ideal de publicidade como fundamento do poder teriam sido fragilizados tanto pela força da mídia de massas, presa a uma dinâmica comercial totalizante e despolitizante, quanto pela submissão dessa mesma mídia de massas a interesses corporativos e partidários, os quais retirariam aquela autonomia que ela possuía frente ao poder institucionalizado no Estado e, posteriormente, nos partidos políticos profissionais (cf. HABERMAS, 1970, p. 20; HABERMAS, 2002, p. 197; HABERMAS, 2003b, p. 268). 
A mudança estrutural da esfera pública, por conseguinte, estaria em que, de um modo geral, a esfera pública das democracias de massa do século $\mathrm{XX}$, concentrada eminentemente na mídia corporativa e ligada ao Estado burocrático e aos partidos políticos profissionais, ao mesmo tempo em que enredada em uma dinâmica comercial dependente de investimentos do capital privado, teria náo apenas perdido sua autonomia diante dos interesses de classe em conflito na sociedade, senão que, enquanto quarto poder, transformouse, ela mesma, na instituição ponta-de-lança no que tange à legitimação da própria luta de classes, cujo controle determinaria, em grande medida, a própria hegemonia político-cultural dos grupos de poder privados. Em seu surgimento, a esfera pública burguesa constituía-se enquanto espaço social no qual indivíduos e grupos privados discutiam assuntos ligados à sociedade, de um modo geral, em uma postura aberta de crítica ao poder, de fiscalização do mesmo e exigente de sua legitimação; sua tendência à subversão (mudança estrutural concebida, em um sentido negativo, como massificação, alienação, solapamento do potencial de crítica da esfera pública, por meio da associação entre tecnocracia e cultura de massas), desde o século XX, transformou-a em um espaço ideológico de legitimação de interesses privados que se pretendiam públicos e, portanto, buscavam hegemonia na sociedade como um todo função que, como acredita Habermas, a mídia corporativa assumiu de maneira exemplar, não apenas em termos comerciais, mas também em termos políticos, correlatamente à consolidação de uma postura tecnocrática em termos de administração estatal e ao engessamento burocrático e elitista dos partidos políticos em relação à massa dos cidadãos.

Assim, se, no modelo sociológico e filosófico-normativo de esfera pública burguesa, tematizado por Habermas, um ideal de publicidade apontava para a percepção de que seria possível justificar interesses públicos enquanto interesses de toda a sociedade e de seus grupos constituintes (racionalmente concebidos), os quais deveriam servir como parâmetro para a avaliação do poder estatal e partidário, assim como das açốes dos próprios grupos privados em suas pretensôes frente às instituições públicas, a degeneração da esfera pública das democracias de massa contemporâneas teria imprimido a esse mesmo ideal de publicidade uma descaracterizaçáo ideológica que solapou, em grande medida, a possibilidade de estabelecer-se padrôes objetivos no que tange à definição de interesses genuinamente universalistas, públicos, em face das posiçóes de classe privadas. Na verdade, a esfera pública concentrada e detonada a partir da mídia corporativa levaria ao ofuscamento dessa possibilidade de definir-se padróes públicos de justificação e de discussão acerca das tomadas políticas 
de decisão, tanto pelo seu distanciamento em relação aos grupos sociais (e em particular dos grupos sociais em situação de marginalização) quanto pelo seu enraizamento em uma dinâmica diretamente comercial. No mesmo sentido, a primazia política dos partidos profissionais e dos políticos carreiristas, como já afirmava Weber (cf. WEBER, 1968, p. 63-67), teria afastado a sociedade civil, com suas iniciativas cidadãs e seus movimentos sociais, da esfera pública e, em particular, da possibilidade de um contato mais efetivo com o âmbito da política parlamentar (cf. HABERMAS, 2001a, p. 33; MILIBAND, 1972, p. 147-178). Com isso, a ideia de uma política radical, nas democracias de massa contemporâneas, teria perdido muito da sua eficácia, devendo encontrar outro substrato normativo e um renovado impulso sociocultural que não ficassem presos ou monopolizados nem na estrutura estatal e partidária e nem naquela esfera pública canalizada pela mídia corporativa. Ora, a sociedade civil, em seus movimentos sociais e suas iniciativas cidadâs, juntamente com formas de organização política marginais e mídias alternativas, favoreceria o surgimento de esferas públicas informais, eminentemente críticas do poder, as quais poderiam oferecer complemento normativo e sociocultural ao poder centralizado no Estado e dinamizado pelos partidos políticos profissionais. Essas esferas públicas informais, marginais, seriam utilizadas por iniciativas cidadãs e movimentos sociais que não estariam diretamente ligados a interesses de classe (no sentido marxiano) e nem mobilizados pela busca do poder a qualquer custo, mas sim orientados para o bem comum, em uma atitude solidária diante das suas comunidades e mais além.

\section{DA LEGITIMAÇÁO NORMATIVA DO PODER DEMOCRÁTICO}

Para Habermas, uma política radical é a exigência de uma esfera pública renovada. Essa política radical, na verdade, teria sido possibilitada exatamente pelas revoluçôes burguesas e proletárias modernas (enquanto complemento, como acredita o referido pensador - cf. HABERMAS, 2001b, p. 505-509), calcadas no poder emancipatório emanado da sociedade civil que, desde a modernidade, com seus atores políticos e servindo como arena política, daria a tônica da evolução das sociedades ocidentais, em processo de democratização. Nesse aspecto, a sociedade civil moderna representaria o impulso políticocultural e o fundamento normativo do próprio poder institucionalizado no Estado e nos partidos políticos profissionais. Se, de um lado, tanto Estado quanto partidos políticos assumiriam - como aconteceu ao longo do século XX - a prerrogativa no que tange à condução administrativo-legislativa da evolução 
social, de outro lado a sociedade civil e seus atores políticos mantiveram essa tarefa de legitimar permanentemente, com base em interesses generalizáveis e em argumentos normativos, a autoconstituição e o exercício do próprio poder. É aqui, por conseguinte, que uma política democrática radical e a esfera pública política imbricam-se ferreamente: pois, não se pode fazer política sem um processo permanente de justificação pública que as administraçóes e os partidos políticos têm de realizar perante a sociedade civil e seus atores políticos - uma justificação que, diga-se de passagem, náo é meramente técnica, como uma prestação de contas pura e simplesmente, senão que adquire, no mais das vezes, uma ligação direta com a fundamentação normativa desse mesmo poder, baseada em interesses generalizáveis. $\mathrm{O}$ fundamento do poder institucionalizado e da hegemonia político-partidária advém do processo de justificação que, em uma situação de publicidade, conecta os grupos aspirantes ao poder com as expectativas sociais e os interesses dos cidadãos e dos grupos sociais, permitindo que suas propostas sejam submetidas ao escrutínio dos mesmos e, nesse aspecto, dissecadas em seus princípios mais básicos, complementadas e, conforme sua situação, aperfeiçoadas ou descartadas. $\mathrm{O}$ fato é que, conforme penso, a necessidade de justificação pública, com base em argumentos normativos e interesses generalizáveis, faz com que tanto as administraçóes públicas quanto principalmente os partidos políticos adequem suas programáticas às aspiraçóes sociais e a um ideal de eticidade que diminui sua tendência à burocracia e à corrupçáo, na medida em que o ponto mais importante para sua permanente hegemonia se relaciona com o modo como são vistos e avaliados em suas ações pela população.

Além disso, a esfera pública propicia uma política radical, porque retirou do Estado e dos partidos políticos a capacidade de bastarem-se, no que tange à justificação de suas políticas em particular e de seus conchavos de uma maneira geral. Em primeiro lugar, eles não se bastam em termos de justificação, pelo fato óbvio de que necessitam do apoio majoritário do corpo de cidadãos, devendo, por isso, segundo se disse acima, moldarem sua programática, seus valores e suas açóes de um modo o mais universalista possível e sempre com base em argumentos normativos. Dito de outro modo, os partidos políticos devem ser absolutamente idôneos e ter uma programática vinculada socialmente - esses dois pontos podem conceder ou retirar completamente sua hegemonia pública, para não se falar de sua legitimidade moralmente falando (que, no público de cidadãos de um modo geral, devém do grau de incorruptibilidade e de comprometimento que os mesmos apresentam). Em segundo lugar, portanto, pode-se perceber que a justificativa das administraçóes e dos partidos políticos não é interna 
aos mesmos nem independente dos procedimentos democráticos de discussão e de validação, mas sim vinculada à publicidade e ao grau de aproximação que eles têm em sua relação com a sociedade civil e seus atores políticos. Nesse sentido, as administrações e os partidos políticos devem ir à praça pública com ações, valores e argumentos normativos consistentes, justificando aos cidadáos que trabalharam e que trabalharão para os mesmos e que agem com base em valores universalistas e interesses generalizáveis. Esse ponto, por mais ideal ou mesmo simples que seja, parece-me importante para considerar-se a estruturação das democracias contemporâneas, em sua relação com o poder institucionalizado no Estado e com os partidos políticos em busca de hegemonia: a sociedade civil, com seus múltiplos grupos de crença, com as mais gerais e específicas aspirações de seus cidadáos e mesmo com seus (enquanto sociedade democrática) interesses generalizáveis, monopoliza a justificação normativa do poder, fazendo com que ela - com seus atores políticos e parâmetros normativos - seja a instância que referenda ou deslegitima a validade desse mesmo poder e a hegemonia partidária.

E isso conduz a um terceiro ponto: é que a desconstrução e, na verdade, a retirada da legitimidade do poder do próprio âmbito interno aos meandros do Estado e dos partidos políticos, com seu translado para a - e monopolização na - sociedade civil, constituída a partir da esfera pública político-cultural, esvaziaram a autoridade institucional da capacidade náo apenas de bastar-se a si mesma, mas também de detonar um processo de validação de suas decisóes que possa ser independente e autônomo da esfera pública dinamizada pelos movimentos sociais e pelas iniciativas cidadãs. A autoridade política, conforme penso, foi tão ou mais afetada que a autoridade religiosa e tradicional pelo processo de secularização, no sentido de que ela, por meio das atividades político-culturais dos cidadáos e dos grupos sociais, foi completamente desconstruída em sua validade e em sua pureza internas. Desconfia-se permanentemente da autoridade e do poder institucionalizado, debocha-se e caricatura-se deles e com eles, deixa-se com muita facilidade de confiar neles e, principalmente, muda-se de posição de acordo com a avaliação pessoal que se faz das açóes e dos valores que eles propugnam e realizam. Essas açóes, levadas a efeito pelos grupos político-culturais presentes na sociedade civil, especificam o quanto o poder institucionalizado perdeu a autoridade em termos de justificação perante o público democrático: o ceticismo que se sente em relação ao poder é acompanhado de uma necessidade cada vez mais premente que as administrações e os partidos políticos têm de legitimaremse normativamente perante os cidadãos e os grupos sociais, sem os quais eles nada são ou alcançam. 
Ora, o aspecto mais importante da dinâmica hodierna em termos de sociedade civil, que esses exemplos procuraram captar, está em que ela possui uma significação mais ampla do que aquele sentido moderno, enfatizado sobremaneira por Hegel e Marx, de uma esfera das necessidades determinada pela dinâmica do mercado capitalista (cf. HABERMAS, 2003b, p. 99) - o que, por sua vez, fortalece o argumento que defendo aqui, a saber, de que a esfera pública política das nossas democracias permite pensar-se um modelo de política radical altamente emancipatório e socioculturalmente inclusivo. Com efeito, consoante Habermas, a sociedade civil hodierna apresenta novo significado e, conforme quero enfatizar neste artigo, renovado alcance político-cultural que a colocam, com suas forças político-culturais e suas arenas não vinculadas ao poder estrutural do Estado, dos partidos políticos e das grandes corporaçôes econômicas (esferas públicas informais que também são alternativas em relação à mídia corporativa), como ponta-de-lança de uma práxis político-cultural emancipatória, que tem condiçóes de dinamizar a evolução de nossas democracias.

Para o referido autor, a sociedade civil das democracias hodiernas é caracterizada por dois pontos que são fundamentais, conforme penso, para formular-se um modelo de política radical que possibilite a viabilização de uma forma de evolução social efetiva e mais abrangente e participativa possível. Ela consiste, por um lado, em um contexto político-cultural caracterizado por iniciativas cidadâs, por movimentos sociais e pelas mais diversas associaçôes e organizaçôes, que se reúnem a partir de vieses político-culturais heterogêneos, os quais, não obstante em muitas situaçóes se remeterem diretamente à proteção dos próprios interesses pessoais e da comunidade de que fazem parte, reafirmam permanentemente a vinculação dos mesmos a interesses universalizáveis e argumentos normativos afirmados enquanto o núcleo ético da democracia. Aqui, por conseguinte, a atuação desses atores políticos liga-se diretamente aos valores universalistas próprios de uma sociedade democrática e, o que é mais importante, não podem afirmar-se sem correlatamente afirmarem o próprio núcleo normativo e universalista da democracia - a validade dos seus interesses liga-se diretamente à validade e ao fortalecimento dos interesses genuinamente democráticos. Por outro lado, como consequência, a sociedade civil das atuais democracias é perpassada pela horizontalidade, no que tange ao acesso e à legitimação do poder, diferentemente da estrutura administrativopartidária e da constituição do mercado capitalista, que são marcados por uma estrutura hierárquica e vertical, em termos de acesso ao poder e de status quo (cf. HABERMAS, 2003b, p. 99). 
Nesse sentido, a cooperação entre iniciativas cidadãs, movimentos sociais e grupos culturais os mais diversos, intermediada solidariamente, imprime uma dinâmica democratizante ao poder e o enquadra com base nessa perspectiva solidária, horizontal e universalista. Tais iniciativas cidadãs, movimentos sociais e grupos culturais, situados equitativamente uns frente aos outros e utilizando-se de espaços públicos informais e de mídias alternativas, permitem concomitantemente o diagnóstico de problemas sociais, a tematizaçáo de questóes político-culturais e uma crítica radical do poder e dos grupos aspirantes ao poder, que os obrigam irremediavelmente a voltarem atenção para as questões de integração sociocultural e para os desafios políticos em termos de evolução democrática, fazendo-os adentrarem a praça pública para justificarem-se diante desse amplo público de cidadáos, de movimentos sociais e de grupos culturais (cf. HABERMAS, 2003a, p. 333; HABERMAS, 2000, p. 119). Afirma-se, com isso, o ponto nodal de uma organização democrática, isto é, a horizontalidade, a igualdade no acesso ao poder, por parte de todos os cidadáos, sem a qual a democracia começa a ser solapada.

Como acredita Habermas, a questão fundamental a ser considerada em relação ao significado contemporâneo da esfera pública, a partir da qual se organiza e se dinamiza a sociedade civil, consiste exatamente em que os movimentos sociais, as iniciativas cidadãs e os grupos culturais mantêm uma postura político-cultural de autonomia em face do poder administrativopartidário e aos interesses econômicos das grandes corporaçóes, o que lhes possibilita essa capacidade de crítica radical ao poder, tâo necessária para fazer-se publicizar náo apenas os problemas estruturais da sociedade e de suas instituiçôes, como também para trazer à luz sua justificação e as possibilidades de transformação que podem ser pensadas em função dos interesses, das forças político-culturais e das condiçôes sociais encontradas. $\mathrm{O}$ fato de a sociedade civil ser composta de iniciativas cidadâs, de movimentos sociais e de grupos e associaçóes culturais, os quais dinamizam esferas públicas autônomas e críticas dos poderes e do status quo constituídos e consolidados, oferecendo alternativas de espaços públicos à mídia corporativa, confere dinamismo à evolução democrática, que, por conseguinte, não fica presa à - e nem dependente da e conduzida apenas pela - esfera administrativo-partidária e, como acontece frequentemente, a partir do direcionamento dado pelos lobbies econômicos. Isso também significa a democratização do próprio acesso ao espaço público, por parte de grupos mais frágeis da sociedade, que não conferem audiência a uma mídia seletiva daquilo que deve ou náo aparecer como público. 
Para a prática da autodeterminação dos cidadãos pressupóe-se uma base na sociedade civil, autônoma, independente da administração pública e do comércio privado mediado pelo mercado, a qual preserva a comunicação política de ser absorvida pelo aparelho do Estado ou de ser assimilada à estrutura do mercado. [...] a esfera pública política e a sociedade civil, como a sua base, obtêm um significado estratégico; elas devem garantir à prática de entendimento dos cidadáos sua força de integração e de autonomia. O desacoplamento da comunicaçáo política da sociedade econômica corresponde, em nossa terminologia, a uma religaçáo do poder administrativo ao poder comunicativo resultante da formação política da opinião e da vontade. (HABERMAS, 2003a, p. 33; os grifos são de Habermas. Cf., ainda: HABERMAS, 1997, p. 452-455; DEAN, 1996, p. 220-242).

A sociedade civil, no seu novo significado contemporâneo, como horizonte político-cultural, constituída por iniciativas cidadãs, por movimentos sociais e por grupos culturais autônomos em relação ao poder institucionalizado, em termos de Estado e de partidos políticos, bem como não vinculados ao poder econômico pura e simplesmente, ao realizar uma crítica permanente do poder, recoloca a evolução democrática em bases normativas e vincula (ou pelo menos problematiza incansavelmente) seja o poder administrativopartidário, seja a própria dinâmica econômica, a interesses generalizáveis que revitalizam o processo democrático de evoluçâo social, ramificando-o em todos os setores da sociedade, passando da política para a cultura e adentrando na economia. Assim, à tendência ao permanente solapamento da esfera pública por parte das grandes corporaçóes econômicas, do Estado burocrático e dos partidos políticos profissionais, utilizando-se da mídia corporativa, esse poder horizontal e calcado na solidariedade, dinamizado pelos atores políticoculturais advenientes dessa sociedade civil anárquica, não domesticada por tais poderes estruturais e nem comprada por eles, oferece um espaço inclusivo, atores políticos e oportunidades equitativas de participaçáo que complementam o poder institucionalizado e purificam-no da influência nefasta do dinheiro na política. Com isso, essa mesma evolução democrática retorna às ruas, aos becos, de onde ela havia genética e normativamente saído, tornando-se acessível ao cidadão comum, aos movimentos sociais e aos grupos culturais os quais acreditam nela e querem efetivamente participar dela. 
ESFERA PÚBLICA, SOCIEDADE CIVIL E DEMOCRACIA RADICAL: POR UMA POLÍTICA ÀS MARGENS

Como se oferecer um contraponto à subversão da esfera pública política e ao distanciamento e à sobreposição dos poderes institucionalizados frente à sociedade civil? Além disso, que alternativa poderia ser encontrada à influência burocrática e elitista dos partidos políticos profissionais, a qual, ao mesmo tempo, refreasse a influência econômica na política? Se, evidentemente, não é possível abdicar deles (e até desses conflitos de classe, por assim dizer, que seriam o pathos das democracias contemporâneas), como complementá-los com outros espaços públicos e atores políticos democráticos? Como trazer normatividade à política, minimizando a influência do dinheiro? A tarefa principal bifurca-se em dois pontos que estão imbricados: ela consiste, primeiramente, em levar-se a sério essa mudança acontecida na modernidade política, caracterizada pela substituição do Estado ou do rei enquanto núcleo do poder e sua (desse mesmo núcleo do poder) transposição para o âmbito da sociedade civil e da esfera pública por ela dinamizada; em segundo lugar, ela aponta para a complementação, em termos de práxis política, da atuação dos partidos políticos profissionais com movimentos sociais, iniciativas cidadãs e os mais diversos grupos culturais, de modo a aproximar aqueles partidos políticos com as bases sociais, ao mesmo tempo em que, com isso, haveria a possibilidade de instaurar-se esferas públicas informais que não estivessem presas à dinâmica totalizante da mídia corporativa - politizando novamente a esfera pública.

Ora, quando Habermas analisa o processo de modernização ocidental - utilizando-se, para isso, de Marx e de Weber (e conferindo, para o estudo do padrão de desenvolvimento das sociedades contemporâneas, maior importância ao segundo) -, as possibilidades emancipatórias e as patologias psicossociais desse mesmo processo de modernização aparecem como sendo originados não apenas pela infraestrutura econômica, como queriam Marx e o marxismo tradicional (cf. HABERMAS, 1990; HABERMAS, 1999), mas também e principalmente, como acreditava Weber, pela tendência à burocratização da política e à apropriação comercial e partidária da mídia, as quais subverteriam a esfera pública política: no primeiro caso, a política enquanto ideal moral seria subvertida pela ideia de uma política orientada para a conquista do status quo, marcada pelos conchavos entre políticos profissionais, cujo propósito central seria o carreirismo e até o sucesso econômico, a partir do uso da máquina pública e de seu orçamento, substituindo a participação das bases pela manipulação das massas de eleitores, que teriam sua importância político- 
cultural solapada pelos burocratas e pelas elites dos partidos; no segundo caso, a mídia seria utilizada, em muitas situações, em função de uma estetização da política, concebida em caráter negativo, como manipulação ideológica de ideias, de práticas e de opiniôes, com vistas exatamente à hegemonia partidária, despolitizando e tornando prescindíveis, politicamente falando, indivíduos e grupos sociais a rigor fundamentais para garantir uma evolução social equalizada entre todos e para todos (cf. WEBER, 1968, p. 79-104; HABERMAS, 2001b, p. 428-543).

Com isso, ainda segundo Weber, a política contemporânea andaria em maus lençóis; e mesmo ele, que se recusava enfaticamente, como homem de ciência, a dar prognósticos sobre o futuro, via a evolução das sociedades democráticas hodiernas com grande pessimismo, exatamente devido ao fato de a política - que seria o fundamento dessa evolução - estar degenerada, deturpada, quer no sentido de uma ênfase como que exclusiva na política parlamentar, cada vez mais burocratizada e afastada de suas bases sociais, quer no sentido de que essa mesma política parlamentar bastaria enquanto uma estetização da política, levada a efeito com o auxílio da mídia corporativa (cf. WEBER, 1968, p. 104-105). A política estaria perdendo seu caráter participativo e consolidando um caráter aclamativo, caracterizado basicamente pela conquista da lealdade das massas e sua despolitização, com a substituição das mesmas pela camada burocrática (tanto em termos de democracias liberais quanto em termos de sociedades comunistas, ainda segundo Weber). Para Habermas, por conseguinte, nessa esteira aberta por Weber, tanto as debilidades quanto as incríveis possibilidades de emancipação detonadas pelas sociedades democráticas contemporâneas apontariam diretamente para a política como o médium a partir do qual tais sociedades alcançariam uma transformação qualitativa ou regrediriam a uma situação de caos social. Com isso, é como práxis político-cultural renovada que se pode retomar um ideal democrático de emancipação social.

E essa práxis político-cultural renovada encontraria seu substrato normativo e seu dinamismo nos espaços públicos alternativos e nos atores políticos emanados da sociedade civil, enquanto esfera político-cultural normativamente estruturada e crítica do poder - conforme seu significado contemporâneo, salientado acima. Com efeito, as esferas públicas informais, detonadas por iniciativas cidadãs, movimentos sociais e os mais diversos grupos culturais, que não estão presas ao poder administrativo-partidário nem ligadas a interesses econômicos estruturais, possuem independência $\mathrm{d}$ radicalidade para 
lidar com os desafios do processo de modernização e, em particular, também para assumir interesses generalizáveis que essa mesma modernidade, com sua cultura política explosiva e crítica dos poderes institucionalizados, instituiu como próprios a uma condição humana de liberdade e de igualdade, segundo padrôes universalistas e mesmo democráticos. Nesse sentido, essa política às margens da estrutura administrativo-partidária representaria, de acordo com Habermas, tanto o substrato normativo do poder quanto, em termos de Realpolitik, seu complemento, no sentido de que, por meio dessa crítica radical do poder, dessa profanaçâo permanente dos poderes instituidos (no sentido de sua desconstrução e chamada à justificação cotidiana), abrir-se-ia espaço para a correção das instituiçóes e de seus procedimentos, correlatamente à resolução daquele problema que, começando com Weber, passando por Horkheimer e Adorno e chegando a Habermas, afetaria a evolução democrática das sociedades contemporâneas, a saber, a autonomização e a sobreposição do aparato administrativo-partidário em relação à sociedade civil, que levaria à subversão da esfera pública política. $\mathrm{O}$ caráter selvagem das esferas públicas informais da sociedade civil hodierna, com seus grupos e iniciativas eminentemente contrapostos ao poder estrutural (burocracia, partidos políticos, dinheiro, mídia corporativa), levaria exatamente ao próprio enquadramento dessa esfera pública desestruturada, concomitantemente à fragilização da independência e da sobreposição do aparato administrativo-partidário em relação à sociedade civil e seus atores políticos.

Os fluxos comunicacionais, em princípio ilimitados, perpassam as esferas públicas organizadas no interior de associaçóes, as quais formam componentes informais da esfera pública geral. Tomados em sua totalidade, eles formam um complexo 'selvagem', que não se deixa organizar completamente. Devido à sua estrutura anárquica, a esfera pública geral está, de um lado, muito mais exposta aos efeitos de repressão e de exclusão do poder social desigualmente distribuído, da violência estrutural e da comunicação sistematicamente distorcida, do que as esferas públicas organizadas do complexo parlamentar, que são reguladas por processos. De outro lado, porém, ela tem a vantagem de ser um meio de comunicação isento de limitaçóes, no qual é possível captar melhor novos problemas, conduzir discursos expressivos de auto-entendimento e articular, de modo mais livre, identidades coletivas e interpretações de necessidades. A formaçấo democrática da opiniấo e da vontade depende de opinióes públicas informais que idealmente se formam em estruturas de uma esfera pública política não-desvirtuada pelo poder. (HABERMAS, 2003b, p. 33. Cf., ainda: HABERMAS, 2002, p. 283; PINZANI, 2009, p. 151-153; MUNNICHS, 2002, p. 185-187). 
O ponto importante, aqui, para o modelo de política radical em questão, consiste no fato de que Habermas considera a esfera pública como a "antessala do sistema parlamentar", como a "[...] periferia que inclui o centro representado pelo Estado" (HABERMAS, 2003b, p. 187; o grifo é meu. Cf., ainda: HABERMAS, 2009, p. 141; SCHEUERMAN, 2002, p. 64-66; BENHABIB, 1997, p. 85-88; FRASER, 1997, p. 111). Trata-se, segundo penso, de um duplo aspecto no que tange à possibilidade desse modelo de política radical. Um aspecto consiste no fato de que o sistema administrativo-partidário não é independente nem está sobreposto em relação à sociedade civil, senão que faz parte do horizonte aberto por ela, seja em termos de programáticas a serem realizadas, seja quanto aos interesses generalizáveis e aos argumentos normativos que justificariam a própria possibilidade de uma práxis política conforme à democracia. $\mathrm{O}$ segundo aspecto, em continuação, está em que a atuação política partidária se torna incapaz de, por si só, realizar uma práxis política substantiva, sobrepondo-se às ruas, isto é, às iniciativas cidadãs, aos movimentos sociais e aos mais diversos grupos culturais: a voz, os interesses e os ideais da estrutura administrativo-partidária precisam estar em consonância com as vozes, os interesses e os ideais das ruas (cf. HABERMAS, 2003a, p. 340). Na verdade, no que concerne a este ponto, fica patente a necessidade de um processo cooperativo que faça os partidos políticos retornarem às suas bases na sociedade civil: sem tal contato estreito, a burocratização e a corrupção darão a tônica de uma política que, ao invés de dinamizar a evolução democrática, emperra-a, porque, centralizada nos partidos políticos profissionais e nas instâncias burocráticas da administração estatal de ocasião, distanciou-se e sobrepôs-se à sociedade civil e aos seus atores políticoculturais (cf. HABERMAS, 2003b, p. 25; MACCARTHY, 1998, p. 137; WOLFE, 1980, p. 331-345). A esfera pública, por conseguinte, representaria a antessala da política parlamentar, porque é ali que tanto a fundamentação quanto os atores políticos e os conteúdos práticos são trazidos à publicidade, discutidos e fundamentados de acordo com o próprio sentido de uma cultura democrática, que é inclusiva, aberta e igualitária entre todos e para todos.

A democracia faz-se por meio da publicidade e da participação ampliada de iniciativas cidadâs, de movimentos sociais e de grupos culturais em parceria com os partidos políticos. Esse foi o princípio mais básico da tensão entre esfera pública burguesa e esfera pública proletária que, desde o século XIX, demarcou muito da dinâmica político-cultural das sociedades ocidentais em processo de democratização. Hodiernamente, a herança que recebemos dessas lutas modernas em torno à esfera pública política, enquanto cidadãos de sociedades democráticas relativamente estáveis, consiste exatamente na força e 
na centralidade de uma esfera pública política que, dinamizada por iniciativas cidadãs, movimentos sociais e grupos culturais radicalmente críticos dos poderes vigentes, impede a autonomia e a sobreposição da estrutura administrativopartidária em relação à sociedade civil, oferecendo contrapontos poderosos à esfera pública centralizada na mídia corporativa. A crítica radical do poder, em tudo isso, transladou-se, em poderosa medida, dos parlamentos para as ruas, dos partidos políticos profissionais para os movimentos sociais, as iniciativas cidadãs e os grupos culturais, que, a partir das esferas públicas informais por eles dinamizadas e das mídias sociais por eles utilizadas, enquadram o poder com base em interesses generalizáveis e argumentos normativos. As ruas, e não mais o parlamento, são a base da democracia - pelo menos a base normativa, o substrato da eticidade da mesma, mas também enquanto forças políticas que enquadram a atuação das administrações e dos partidos políticos. No modelo de política radical habermasiano, a práxis política é dinamizada exatamente com base na normatividade detonada pelas fontes espontâneas originadas da sociedade civil e de seus atores políticos, em sua tentativa de influir nas decisóes partidárias, oferecendo-lhes formas de resistência e temas, evitando que a práxis política seja apenas um tema de elites burocráticas e dinamizada preponderantemente pelo poder do dinheiro (cf. HABERMAS, 2003b, p. 295). A efetiva politização da esfera pública política, assim, tem por motor os movimentos sociais, as iniciativas cidadãs e os mais diversos grupos culturais, com suas formas de resistência, com seus argumentos, com sua força políticocultural e com sua criatividade - eles fazem com que a política volte às ruas e se democratize, bem como permitem, com suas denúncias e atuaçóes autônomas, separar interesses generalizáveis e interesses econômicos oligárquicos.

\section{A Centralidade da política democrática: CONSIDERaÇóes Finais}

Acredito, à guisa de conclusão, que qualquer tentativa filosóficosociológica de pensar-se uma mudança estrutural da esfera pública, ao estilo habermasiano, precisa estar atenta a uma transformação que, das últimas décadas do século XX em diante, aconteceu em nossas sociedades democráticas e mesmo, por assim dizer, em termos de um espaço público internacionalizado, devido tanto ao surgimento, como o próprio autor já chamava atenção em Teoria da Ação Comunicativa, de movimentos sociais e iniciativas cidadãs não mais diretamente ligados aos conflitos de classe em sentido estritamente econômico, quanto à democratização do acesso às mídias e às tecnologias de informação. No primeiro caso, esses movimentos sociais 
e iniciativas cidadâs organizam-se em formas de resistência e de participação que centralizam sua dinâmica nas ruas e nos becos do cotidiano, mas se direcionando à sensibilização do aparato administrativo-partidário e da esfera econômica em relação a problemas sociais, culturais, ecológicos, bem como no que tange a possíveis ações com vistas à resolução desses problemas. No segundo caso, que é o que me interessa agora, pode-se perceber que as mídias sociais possibilitam a consolidação de espaços político-culturais alternativos, informais e espontâneos, nos quais movimentos sociais, iniciativas cidadâs e os mais diversos grupos culturais podem construir arenas de debates, projetar açôes e definir programáticas que, em conquistando adeptos, podem influenciar - e efetivamente influenciam - ações políticas emancipatórias, as quais melhoram as condiçôes sociais do contexto em questão.

Portanto, a mudança estrutural da esfera pública, que Habermas tematizou no livro de mesmo nome, deve ser percebida e trabalhada tendose em vista o fato de que ela, hoje, ainda que vigente enquanto tendência da mídia corporativa e do aparato administrativo-partidário, foi grandemente enfraquecida pela proliferação de movimentos sociais, de iniciativas cidadás e de grupos culturais participativos da vida político-cultural e críticos dos poderes institucionais. Eles consolidam esferas públicas informais que, devido à sua força, freiam qualquer tentativa de centralização do espaço público nessa mídia partidária e corporativa, impedindo, da mesma maneira, a monopolização desse mesmo espaço público por tal mídia corporativa e partidária. Isso significa, por conseguinte, a consolidação de espaços públicos plurais e, no mais das vezes, informais, não ligados diretamente aos poderes estruturais da esfera administrativo-partidária e do âmbito econômico na verdade, esses espaços públicos informais são radicalmente críticos dos poderes estruturais, oferecendo arenas de debates e de açóes inclusivas, universalistas e contrapostas a qualquer forma de segregação social, política e cultural. Não é mero acaso, nesse sentido, que Habermas coloque todo o peso da fundamentação normativa, no que tange à evolução das sociedades democráticas, exatamente nesses espaços públicos informais detonados por meio de iniciativas cidadãs, movimentos sociais e grupos culturais da sociedade civil, que, utilizando-se de mídias alternativas e formas de práxis político-culturais não enquadradas pelos poderes estruturais (Estado, partidos políticos, dinheiro e mídia corporativa), têm de, inevitavelmente, lançar mão de interesses generalizáveis e argumentos normativos. Com isso, esses espaços públicos informais e os atores políticos que os empregam comprometemse com o universalismo moral próprio da modernidade, herdando o caráter 
radicalmente crítico do poder que as revoluçóes burguesas e os movimentos proletários modernos conferiram à sociedade civil e à esfera pública política por ela instaurada.

Hodiernamente, a democracia, enquanto práxis político-cultural inclusiva, torna-se cada vez mais uma realidade em nossas sociedades, na medida em que se dá tal alargamento e pluralização dos espaços públicos, o que correlatamente implica a proliferação e o aumento da participaçáo de iniciativas cidadãs, movimentos sociais e grupos culturais na problematização do processo de evolução social. Isso, como disse acima, publiciza tanto os déficits quanto as potencialidades apresentadas por nossas sociedades, a partir de uma perspectiva plural, a qual não fica monopolizada por poderes estruturais centralizados no âmbito administrativo-partidário e nem enquadrada pura e simplesmente pelo dinheiro. Do mesmo modo, a existência de espaços de opiniāo e de discussão plurais descentraliza e retira o monopólio da mídia corporativa em relação ao espaço público, possibilitando a confrontação de diagnósticos e de posiçôes, tão fundamental para o processo democrático de evolução social. Evita-se, ainda, neste último caso, uma estetizaçáo pura e simples da política, naquele sentido comentado acima, de uma correlata massificação midiática do político, quanto de uma sua deslegitimação dele, o que levaria à despolitização das questôes públicas: a problematização da política a partir desses espaços públicos plurais, levada a efeito por diferentes iniciativas cidadâs, movimentos sociais e grupos culturais, faz saltar as justificações - e as justificaçóes espúrias, em particular - da práxis política e, ao mesmo tempo, explicita a dramaticidade das situaçóes reais de injustiça, de sofrimento e de corrupção, tornando-as públicas e, com o tempo, absolutamente inaceitáveis para cada um de nós, cidadãos. Rompe-se aqui, por fim, o privatismo civil, na medida em que nos vemos com possibilidades de influência e de participaçáo mais abrangentes, e cremo-nos com o direito de falar sobre a res publica - uma conquista importantíssima das redes sociais e dos espaços públicos informais abertos pelas mais variadas iniciativas, movimentos e associações.

Tal exigência de espaços públicos informais e de movimentos sociais e iniciativas cidadãs que possam orientar o aparato administrativo-partidário para transformaçóes estruturais torna-se, correntemente, cada vez mais premente. A crise econômica atual, o decréscimo da economia produtiva e o desemprego estrutural praticamente incontrolável acirram novamente, conforme penso, a contraposição entre dois modelos políticos que se digladiaram de maneira férrea, ao longo dos últimos trinta anos do século XX: social-democracia versus 
neoliberalismo. A disputa que ora se torna cada vez mais aguda consiste, de um lado, na ênfase em um poder político capaz de, por sua centralidade, garantir uma evolução social planejada institucionalmente e calcada em interesses generalizáveis advenientes da sociedade civil e fundados em argumentos normativos, os quais refreiam o processo de acumulação, direcionando-o à realização de metas sociais e de processos de integração material. Aqui, a retomada de um Estado diretivo da evolução social adquire primazia esta, inclusive, é a base da programática da social-democracia europeia, em particular, e da esquerda, de um modo geral, hoje, em termos de democracias ocidentais. De outro lado, tem-se a ênfase em políticas de austeridade, por parte de posiçóes neoconservadoras, que apontam o neoliberalismo atual como alternativa à crise socioeconômica. Aqui, tem-se a primazia do laissezfaire econômico e, por conseguinte, a necessidade de respeitar-se a dinâmica própria dos mercados, que ficam solapados pelas intervençôes estatais e pelas exigências em termos de direitos sociais de cidadania. A ideia de uma evolução social conduzida politicamente, para essas posiçôes neoconservadoras, deveria ser substituída por politicas de austeridade (um termo muito em voga, atualmente, como programática para a resolução da crise) que suavizam o Estado de compromissos sociais ampliados. Quer dizer, a crise socioeconômica seria causada pelo Estado de bem-estar social ineficiente, que, por isso mesmo, deveria ser enxugado em suas funçóes, tendo-se afirmada a própria dinâmica econômica como elemento fundamental para a resolução da crise, muito mais do que a esfera política - um argumento que já Hayek defendia enfaticamente, na segunda metade do século XX.

Nesse contexto, assiste-se ao fortalecimento da política às margens frente à política institucionalizada e midiática, isto é, das vozes das ruas e dos becos, as quais exigem um debate mais apurado e inclusivo sobre as causas e as possíveis soluçôes dessa crise socioeconômica e buscam fazer-se ouvir pelos poderes institucionalizados e por uma mídia corporativa que, de um modo geral, dá por assentada tanto a crise quanto a causa política e em termos de direitos sociais para tal crise, em uma clara tentativa de despolitizá-la e aos próprios movimentos de protesto. Do mesmo modo, nesse mesmo contexto, percebe-se a consolidação de uma esfera pública informal que, se, de um lado, não está institucionalizada em termos administrativos e partidários, e nem conta com um espaço público ao estilo da mídia corporativa, pretendese, de outro lado, tão relevante, na discussão sobre a crise quanto o próprio espaço administrativo-partidário. Tomando partido pela importância da diretiva política da evolução social, penso que a hegemonia de forças 
políticas comprometidas com um projeto de emancipação que coloca exatamente a política social como fundamental precisa escorar-se em tais grupos e espaços públicos alternativos, correlatamente à apropriação de seus argumentos normativos e à sensibilização para suas necessidades sociais. A política institucionalizada no Estado e nos partidos políticos somente pode sobreviver como forma política adotada em nossas sociedades, rompendo ainda com sua tendência burocrática e elitista e refreando o poder do dinheiro na própria política, se der um passo além de si mesma, adentrando nas esferas públicas informais radicalmente críticas dos poderes e do status quo vigentes, interagindo com as iniciativas cidadãs e com os movimentos sociais advenientes da sociedade civil - consolidando, de maneira correlata, formas de comunicação pública e de participação social ampliadas, as quais levem em conta as necessidades sociais e os anseios da população comum, que, de um modo geral, não consegue fazer-se ouvir politicamente com tanta força. As políticas de austeridade, nesse aspecto, andam na contramão dessa tendência aberta pelas condiçôes socioculturais contemporâneas de uma política mais radical, abrangente e inclusiva, eminentemente dependente dos impulsos sociais, na medida em que (tais políticas de austeridade) se fecham às vozes das ruas e alimentam-se de uma mídia corporativa que, com suas funçóes despolitizadoras ou mesmo com sua estetização da política, apaga os espaços alternativos de discussão e de publicidade, bem como os atores políticos dinamizadores destes espaços públicos informais. Superar tal cisão é o desafio permanente de nossas sociedades.

Crise e retomada da política: eis a situação sui generis de nossa época. Crise da politica, devido ao fato de que a atual crise socioeconômica carrega de maneira escancarada o fato de que a política é posta em xeque: a tensão real que está por trás da crise socioeconômica e das forças teórico-políticas que se digladiam em vários países ocidentais consiste exatamente na reformulação da política, tanto para aqueles que ainda acreditam que o específico das sociedades modernas seja a afirmação da política e do Estado, enquanto forças diretivas da evolução social, quanto para aqueles que, ao contrário, creem que a característica eminentemente moderna de nossas sociedades consista na afirmação do mercado como o horizonte garantidor da evoluçáo social. Para os segundos, representados pelo neoliberalismo, a anulação da política equivale à anulação da sociedade civil, enquanto arena político-cultural de caráter normativo e radicalmente crítica do poder, a qual não possuiria interesses generalizáveis nem fundamentaçáo normativa enquadradores do poder administrativo-partidário. Para os primeiros, representados pela 
esquerda de um modo geral, a reafirmação de uma política forte e diretiva da evolução social somente pode ser feita se, correlatamente, aproximasse a práxis política dos movimentos sociais e das iniciativas cidadãs advenientes da sociedade civil, nas esferas públicas informais que estes instauram, frente à estrutura administrativo-partidária, ao mercado e à mídia corporativa. Retomada da política, portanto, devido a dois motivos: o primeiro deles é que a resolução da crise acontecerá politicamente, ou pela retomada de uma política forte, ou pela anulação da política, enquanto instância diretiva da evolução social; e, com isso, como segundo deles, porque a crise socioeconômica hodierna acirra a tensão acima comentada, entre laissez-faire econômico versus política forte e diretiva da evolução social, de modo que, para impor-se uma alternativa politica à crise, há de buscar-se apoio político-cultural em termos de sociedade civil e, aqui, afirmando-se uma política radical como própria de uma sociedade democrática caracterizada por padróes universalistas e normativos de integração social. Não existem muitas alternativas para uma democratização efetiva e para a afirmação de uma política forte: uma evolução social democrática deve fazer-se como política radical, como aproximação estreita entre poder administrativo-partidário $e$ argumentos normativos e interesses generalizáveis emanados das esferas públicas informais, dinamizadas pelos movimentos sociais, pelas iniciativas cidadãs e pelos grupos culturais da sociedade civil.

DANNER, Leno Francisco. The public sphere and radical politics: some notes based on Habermas. Trans/Form/Ação, Marília, v. 38, n. 3, p. 133-154, Set./Dez., 2015.

\footnotetext{
ABSTRACT: This paper discusses the Habermasian notion of public sphere. It is argued that the intrinsic association between the public sphere and democracy allows for the development of a model of radical politics in which the approximation between the bureaucratic state and professional political parties, along with social movements and citizen initiatives, could overcome the reduction of political praxis to partisan politics. This would include giving basic importance to normative impulses and universalistic claims coming from civil society. It would also involve regenerating a conception of the public sphere that is not undermined by ideological or distorted forms of communication, including the critique of power. For this, however, political praxis needs, along with such that approximation, to take a step beyond the public sphere concentrated in corporate media, focusing instead on the informal public spheres developed by social movements and citizen initiatives. In fact, Habermas' claimed degeneration of the public sphere of contemporary mass democracies can only be overcome by a major emphasis on informal public spheres. This could energize administrative-party organizations, currently
} 
characterized by detachment and overlap in relation to civil society - a situation largely enabled by corporate media, the bureaucracy, and party elitism.

KEY-WORDS: Public Sphere. Democracy. Degeneration. Informal Public Sphere. Radical Politics.

\section{REFERÊNCIAS}

BENHABIB, Seyla. Models of public space: Hannah Arendt, the liberal tradition, and Jürgen Habermas. In: CALHOUN, Craig (Ed.). Habermas and the public sphere. 5. ed. Cambridge, MA: The MIT Press, 1997.

DEAN, Jodi. Civil society: beyond the public sphere. In: RASMUSSEN, David (Ed.). The Handbook of critical theory. Oxford: Blackwell Publishers, 1996. p. 220-242.

FRASER, Nancy. Rethinking the Public Sphere: a Contribution to the Critique of Actually Existing Democracy. In: CALHOUN, Craig (Ed.). Habermas and the public sphere. 5. ed. Cambridge, MA: The MIT Press, 1997.

GOODE, Luke. Jürgen Habermas: democracy and the public sphere. London: Pluto Press, 2005.

HABERMAS, Jürgen. Toward a rational society: student protest, science and politics.

Translated by Jeremy J. Shapiro. Boston: Beacon Press, 1970.

. Mudança estrutural da esfera pública: investigaçóes quanto a uma categoria da

sociedade burguesa. Tradução de Flávio R. Kothe. Rio de Janeiro: Tempo Brasileiro, 1984.

Teoría y práxis: estudios de filosofía social. Traducción de Salvador Mas Torres y de Carlos M. Espi. Madrid: Tecnos, 1987.

. Para a reconstrução do materialismo histórico. Tradução de Carlos Nelson

Coutinho. São Paulo: Brasiliense, 1990.

. Further reflections on the public sphere. In: CALHOUN, Craig (Ed.). Habermas and the public sphere. 5. ed. Cambridge, MA: The MIT Press, 1997.

_. Problemas de legitimación en el capitalismo tardio. Traducción de José Luis

Etcheverry. Madrid: Cátedra, 1999.

- Más allá del estado nacional. Traducción de Manuel Jiménez Redondo. México: Fondo de Cultura Económica, 2000.

. Diagnósticos do tempo: seis ensaios. Organização e Tradução de Flávio Beno

Siebeneichler. Rio de Janeiro: Tempo Brasileiro, 2001a.

- Teoría de la acción comunicativa. Traducción de Manuel Jiménez Redondo. Madrid: Taurus, 2001b. v. 2: Crítica de la razón funcionalista. 
- A Inclusão do outro: estudos de teoria política. Tradução de George Sperber e de Paulo Astor Soethe. São Paulo: Loyola, 2002.

. Direito e democracia: entre facticidade e validade. Traduçáo de Flávio Beno

Siebeneichler. Rio de Janeiro: Tempo Brasileiro, 2003a. v. 1.

. Direito e democracia: entre facticidade e validade. Tradução de Flávio Beno

Siebeneichler. Rio de Janeiro: Tempo Brasileiro, 2003b. v. 2.

. Ay, Europa! : pequeños escritos políticos. Traducción de José Luis López de Lizaga, Pedro Madrigal y Francisco Javier Gil Martín. Madrid: Trotta, 2009.

MCCARTHY, Thomas. Legitimacy and diversity: dialectical reflections on analytic distinctions. In: ROSENFELD, Michel; ARATO, Andrew (Eds.). Habermas on law and democracy: critical exchanges. Berkeley: University of California Press, 1998.

MILIBAND, Ralph. O Estado na sociedade capitalista. Tradução de Fanny Tabak. Rio de Janeiro: Zahar, 1972.

MUNNICHS, Geert. Rational politics? : an exploration of the fruitfulness of the discursive concept of democracy. In: VON SCHOMBERG, René; BAYNES, Kenneth (Eds.). Discourse and democracy: essays on Habermas' Between Facts and Norms. New York: State University of New York Press, 2002.

PINZANI, Alessandro. Habermas. Porto Alegre: Artmed, 2009.

SCHEUERMAN, William E. Between radicalism and resignation: democratic theory in Habermas' Between Facts and Norms. In: VON SCHOMBERG, René; BAYNES, Kenneth (Ed.). Discourse and democracy: Essays on Habermas' Between Facts and Norms. New York: State University of New York Press, 2002.

WEBER, Max. A Política como vocação. In: . Ciência e política: duas vocaçóes.

Tradução de Leônidas Hegenberg e Octany Silveira da Mota. São Paulo: Cultrix, 1968. WOLFE, Alan. Los límites de la legitimidad: contradicciones políticas del capitalismo contemporáneo. Traducción de Teresita Eugenia Carbó Pérez. Madrid: Siglo Veintiuno, 1980 .

3 Recebido / Received: 18/03/2015

Aprovado / Approved: 27/05/2015 
DANNER, L. F. 